\title{
ANALISIS FAKTOR-FAKTOR YANG MEMPENGARUHI PERILAKU PEMBELIAN IMPULSIF KONSUMEN TOKOPEDIA MENGGUNAKAN ANALISIS DISKRIMINAN (Studi Konsumen Generasi Y dan Z Pada Masa Pandemi COVID-19)
}

\author{
Meria Christina Noviolita ${ }^{1}$, Puji Isyanto ${ }^{2}$, Asep Darojatul Romli ${ }^{3}$ \\ mn16.merianoviolita@mhs.ubpkarawang.ac.id; puji.isyanto@ubpkarawang.ac.id; \\ asep.dj@ubpkarawang.ac.id
}

\begin{abstract}
Abstrak
Tujuan penelitian ini untuk (1) mengetahui perbedaan antara dua kategori konsumen dalam melakukan pembelian impulsif di Tokopedia; (2) mencari faktor - faktor apa saja yang mempengaruhi dua kategori tersebut; (3) memperoleh model diskriminan dua faktor yang terbentuk; (4) mengetahui ketepatan hasil mengklasifikasi kasus dari model diskriminan tersebut. Manfaat penelitian ini diharapkan dapat menjadi dasar untuk penelitian berikutnya, serta menambah wawasan baru bagi program studi manajemen pemasaran. Penelitian dilakukan dengan menggunakan metode deskriptif asosiatif hubungan kausal dengan metode analisis diskriminan, serta mempelajari literatur yang berkaitan dengan topik penelitian, dan penyebaran angket sebagai data primer. Berdasarkan hasil analisis, maka diperoleh dua variabel yang layak dianalisis, yaitu jenis kelamin dan pendapatan konsumen. Model diskriminan dua faktor yang terbentuk adalah Zscore $=-13,737+1,911$ (jenis_kelamin) $+0,875$ (pendapatan). Pengujian validasi diperoleh angka ketepatan yaitu 59\%, maka fungsi diskriminan tersebut dapat digunakan untuk memprediksi kasus kategori konsumen Tokopedia.

Kata Kunci : Perilaku Konsumen, Faktor Pengaruh, Pembelian Impulsif.
\end{abstract}

\begin{abstract}
Absract
The purpose of this study was to (1) find out the differences between the two categories of consumers making impulsive purchases on Tokopedia; (2) looking for the factors that affect the two categories; (3) obtain a two-factor discriminant model that is formed; (4) knowing the accuracy of the results of classifying cases from the discriminant model. The benefits of this research are expected to be the basis for further research, as well as add new insights to the marketing management study program. The research was conducted using the descriptive associative causal relationship with the discriminant analysis method, as well as studying the literature related to the research topic, and distributing questionnaires as primary data. Based on the results of the analysis, there are two variables that are worth analyzing, namely gender and consumer income. The two-factor discriminant model that is formed is $Z$ score $=-13,737+1,911$ (gender) +0.875 (income). In the validation test obtained the accuracy number is 59\%, then the discriminant function can be used to predict cases of the Tokopedia consumer category.

Keywords : Consumer Behaviour, Influence Factor, Impulsive Buying.
\end{abstract}




\section{PENDAHULUAN}

Ditengah pandemi saat ini, hampir sebagian besar masyarakat diberbagai belahan dunia akan menghabiskan waktunya untuk berkegiatan dari dalam rumah, hal ini merupakan upaya yang dilakukan pemerintah ataupun kesadaran diri sendiri terhadap pencegahan wabah COVID-19. Banyak sekali upaya-upaya yang telah dilakukan pemerintah guna memutus tali rantai penyebaran virus ini diantaranya seperti, menayangkan iklan layanan masyarakat yang memuat infoinfo seputar pencegahan, melakukan social distancing (pembatasan jarak) hingga menetapkan kebijakan PSBB (Pembatasan Sosisal Berskala Besar), selain itu pemerintah juga menghimbau agar proses belajar bagi siswa-siswi dan bekerja bagi sebagian besar perusahaan dilaksanakan dari rumah (work from home). Dengan demikian, sebagian besar masyarakat Indonesia melakukan berbagai aktivitas dari rumah dengan kecenderungan memanfaatkan teknologi yang ada, salah satunya ialah smartphone yaitu sebuah perangkat teknologi canggih yang digunakan untuk menjalankan pekerjaan atau hanya sekedar alat pencari informasi diinternet.

Dengan perkembangan teknologi yang begitu cepat meningkat, setiap orang berusaha keras ikut menjadi bagian dalam perkembangan dunia yang menjurus kepada kemjuan zaman yang semakin modern, seperti dengan memanfaatkan teknologi gadget. Dewasa ini, sangat ramai sekali pembahasan mengenai kegiatan jual-beli online. Hal ini dikarenakan proses ekonomi ini sangatlah menjanjikan dikarenakan pasar sasaran yang tidak terhingga, dalam upaya mempromosikan atau mencari mencari pangsa pasar melalui dunia maya maka diperlukan sebuah sarana teknologi untuk menunjangnya. Hal tersebut bertujuan untuk memberi kemudahan bagi produsen maupun konsumen dalam melakukan sebuah transaksi secara online.

Sebuah kegiatan bisnis online yang sedang ramai diperbincangkan ialah dengan bergabung menjadi pengguna marketplace, hal ini dikarenakan calon penjual tidak perlu mengeluarkan biaya tambahan untuk melakukan promosi, sebab pihak penyedia layanan sudah memberikan tempat.

Saat ini khususnya di Indonesia telah banyak bermunculan bisnis marketplace maupun e-commerce dengan ciri dan penawaran yang cukup beragam. Tokopedia ialah salah satu online marketplace terdepan di Indonesia yang paling banyak dikunjungi. Tokopedia dapat menjamin setiap individu, toko 
- toko kecil, dan merk lokal untuk berkesempatan membuka dan mengelola toko daring. Saat peluncurannya pada tahun 2009 hingga kini, layanan dasar dari Tokopedia bisa dimanfaatkan oleh semua pengguna secara bebas.

Dengan maraknya marketplace jual-beli online tersebut, maka untuk meningkatkan kegiatan penjualan dalam memasarkan produk ataupun jasa, para pelaku usaha akan melakukan berbagai upaya apapun guna mempromosikan produk atau jasa yang ditawarkannya tersebut.

Akan tetapi, sebuah kegiatan promosi yang berlebih terkadang memberikan pengaruh bagi perilaku konsumen untuk melakukan pembelian yang berlebih secara tidak rasional, dan tanpa mencari informasi lebih mengenai produk tersebut. Hal ini dikenal dengan istilah perilaku konsumtif. Salah satu aspek dari perilaku konsumtif ialah pembelian impulsif (impulse buying), atau suatu tindakan pembelian yang sebelumnya tidak diakui secara sadar sebagai hasil dari suatu pertimbangan atau niat membeli yang terbentuk sebelum memasuki toko. Dalam hal ini konsumen dalam membeli suatu produk bukan lagi untuk memenuhi kebutuhannya, namun semata-mata hanya untuk memuaskan keinginan dan kepuasanya, terlebih dengan kurangnya kegiatan tambahan diluar rumah maka konsumen akan terus terpaku dengan gadget yang sedang digunakannya.

Perilaku konsumtif erat kaitannya dengan proses pembelian secara berlebih, terutama untuk kalangan milenial golongan generasi Y dan Z. Generasi dengan rentang kelahiran tahun 1977-2012 ini lebih cepat beradaptasi dengan perkembangan teknologi. Usia merupakan faktor demografis lain yang mempengaruhi emotional shopping. Konsumen yang tergolong muda lebih mungkin untuk menjadi pembeli emosional daripada konsumen yang lebih tua. Sebuah buku yang bertemakan manajemen ritel menjelaskan bahwa, konsumen saat ini lebih selektif, terutama anak-anak muda. Mereka kini lebih mengikuti tren yang umum dan disesuaikan dengan kondisi keuangan mereka untuk memenuhi kebutuhan. Dilihat dari tinjauan literatur, beberapa para ahli dunia telah melakukan penelitian yang mengungkapkan faktor pengaruh dari timbulnya perilaku pembelian impulsif (impulse buying) pada diri konsumen. Dengan demikian dapat disimpulkan, bahwa terdapat beberapa penemuan yang mengungkapkan adanya faktor internal dan eksternal yang mendasari terbentuknya perilaku konsumtif dalam diri seseorang. 


\section{TUJUAN PENELITIAN}

Merujuk dari identifikasi perumusan masalah diatas maka tujuan penelitian ini adalah :

1. Untuk mengetahui perbedaan yang signifikan antara konsumen yang membeli produk tak terencana dengan konsumen yang membeli produk secara terencana.

2. Untuk mencari faktor-faktor apa saja yang mempengaruhi perilaku dalam pembelian impulsif pada konsumen Tokopedia.

3. Untuk memperoleh model diskriminan dua faktor yang terbentuk.

4. Untuk mengetahui ketepatan hasil mengklasifikasi kasus dari model diskriminan tersebut.

\section{TINJAUAN PUSTAKA}

\section{Pembelian Impulsif (impulse buying)}

Pembelian impulsif merupakan aspek penting dalam perilaku konsumen atau konsep vital bagi peritel sebab pembelian tidak terencana yang dilakukan oleh konsumen secarang langsung akan berkontribusi pada nilai omset penjualan yang didapat oleh peritel tersebut (Abdolvand et al., (2011), dalam Sari dan Indrawati 2018)).

Menurut Utami (2017:61-62), menjelaskan bahwa perilaku pembelian yang tidak direncanakan (Unplaned Buying) merupakan perilaku pembelian yang dilakukan di dalam toko, di mana pembelian berbeda dari apa yang telah direncanakan oleh konsumen pada saat mereka masuk ke dalam toko. Pembelian tidak terencana adalah suatu tindakan pembelian yang dibuat tanpa direncanakan sebelumnya, atau keputusan pembelin dilakukan pada saat berada di dalam toko. Pembelian tak terencana bisa terjadi ketika seorang konsumen merasa familier dengan tata ruang toko, dibawah tekanan waktu, atau seseorang yang teringat akan kebutuhan untuk membeli sebuah unit ketika melihat pada rak di toko. Beberapa pembelian tidak terencana mungkin ditimbulkan oleh stimulus atau rangsangan dalam toko, sedangkan yang lain mungkin tidak direncanakan sama sekali akan tetapi dikarenakan perilaku yang terungkap. 
Selanjutnya Mowen dan Minor (2010:106) menjelaskan bahwa pengertian pembelian impulsif adalah: sebuah kegiatan pembelian mendadak tanpa ada perencanaan terlebih dahulu pada saat memasuki suatu toko. Sama halnya dengan proses pembelian impulsif secara online, yang diawali dengan membuka web terkait tanpa adanya motif pembelian tertentu dari barang tertentu. Saat melakukan browsing, paparan terhadap berbagai rangsangan eksternal mendesak konsumen untuk melakukan pembelian impulsif. Setelah melakukan pembelian impulsif, mereka mungkin merasa puas atau menyesal.

Faktor - faktor yang mempengaruhi pembelian impulsif diantaranya ialah:

\section{a. Jenis kelamin,}

Penelitian Lin Lin dalam (Renanita, 2017) menyatakan jika wanita memiliki kecederungan untuk lebih impulsif dalam berbelanja daripada pria. Namun di era pasar yang semakin kompetitif ini, dimana perubahan situasi dari pasar secara konvensional menjadi pasar online tentu dapat mempengaruhi pembelian. Kemudian perubahan dalam metode pembelian hingga metode pembayaran juga dapat menjadi daya tarik tersendiri bagi para konsumen, baik wanita maupun pria.

\section{b. Kualitas web,}

Menurut Sharma dan Lijuan dalam (Godara \& Bishnoi, 2019), kualitas situs web dapat menarik pelanggan baru dan mempertahankannya, serta kualitas situs weblah yang membantu konsumen untuk memilih situs web tertentu.

\section{c. Kualitas produk,}

Menurut Kotler and Keller (2016:11), kualitas produk adalah kemampuan suatu barang untuk memberikan hasil atau kinerja yang sesuai bahkan melebihi dari apa yang diharapkan konsumen.

\section{d. Potongan harga,}

Menurut Simamora (2010:154) menjelaskan bahwa, potongan harag merupakan potongan tunai yang ditawarkan kepada pelanggan yang membeli barang-barang dagangan secara kredit.

\section{e. Mood konsumen}

Proses pembuatan keputusan dalam pembelian impulsif sedikit banyak dipengaruhi oleh masalah kognisi dan afeksi dalam diri seseorang, di mana segi afeksi lebih menonjol dibandingkan sisi kognisi, yang lebih banyak dipengaruhi 
oleh stimuli eksternal. Afektif, yaitu proses psikologis dalam diri seseorang yang merujuk kepada emosi, perasaan maupun suasana hati (mood).

\section{f. Display toko,}

Menurut Levy dan Weitz (2012:521), pengaruh keadaan toko adalah kombinasi dari karakteristik fisik toko, diantaranya ialah desain atau hiasan yang digunakan. Display produk adalah salah satu metode penyususnan objek dalam urutan yang sempurna untuk mengetahui ketersediaan produk di toko.

\section{KERANGKA PEMIKIRAN}

Berdasarkan kajian teori yang telah dibahas maka kerangka pemikiran dalam penelitian ini adalah sebagai berikut:

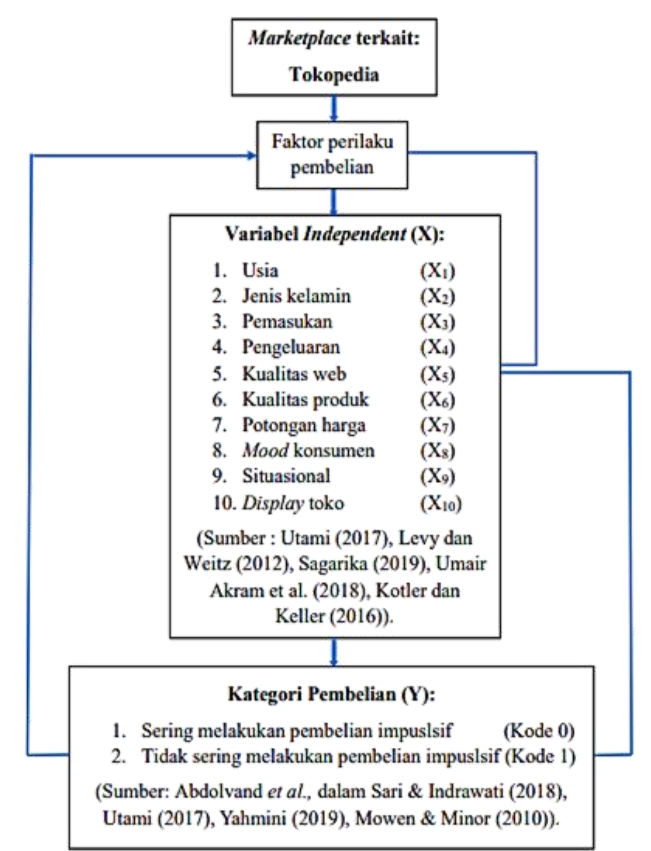

Gambar 1. Kerangka Pemikiran

\section{METODOLOGI PENELITIAN}

\section{Populasi dan Sampel}

Populasi dalam penelitian ini yaitu seluruh konsumen Tokopedia, yang mana diketahui pada periode kuartal III tahun 2019 mencapai \pm 66.000 .000$ pengunjung (termasuk generasi Y dan Z). Adapun dalam penarikan sampel pada penelitian ini menggunakan teori Roscoe (dalam Sugiyono, 2018:133) menyatakan, bila dalam penelitian yang melakukan analisis dengan multivariate, maka jumlah anggota sampel minimal 10 kali dari jumlah variabel yang diteliti. 
Dengan demikian perhitungan kisaran jumlah sampel yang akan diambil ialah sebagai berikut:

Jumlah variabel penelitian $\quad: 10$

Anggota sampel dari jumlah variabel : 10

Maka, 10 × 10 = 100 sampel.

Sampel yang diambil berdasarkan teknik judgment sampling atau purposive sampling, "purposive sampling adalah teknik pengambilan sampel dengan pertimbangan atau kriteria-kriteria tertentu." Adapun kriteria sampel yang akan digunakan meliputi:

- Minimal berbelanja 1 kali dalam sebulan.

- Jarak usia reponden yaitu 10-43 tahun.

\section{Alat Analisis}

\section{Analisis Diskriminan}

Adapun model persamaan yang dipergunakan menurut Santoso (2017:155) adalah sebagai berikut:

$$
\frac{\mathrm{Y} 1}{\text { Non-metrik }} \frac{\mathrm{X} 1+\mathrm{X} 2+\mathrm{X} 3+\ldots+\mathrm{Xn}}{\text { Metrik }}
$$

\section{Non-metrik Metrik}

$$
\begin{aligned}
\underset{\mathrm{Y}}{\operatorname{Dimana}} \mathrm{:} & =\text { Impulse Buying } \\
\mathrm{X} & =\text { Faktor-faktor } \\
& \text { yang mempengaruhi }
\end{aligned}
$$

\section{Pengujian Asumsi}

Pengujian asumsi diskriminan dilakukan dengan menggunakan uji:

\section{Uji Normalitas}

Pengujian ini bertujuan untuk mengetahui apakah distribusi sebuah data mengikuti atau mendekati distribusi normal, yakni distribusi data dengan bentuk lonceng (bell shaped).

\section{Uji Kesamaan Matriks Varians-Kovarians}

Pengujian ini bertujuan untuk mengetahui apakah sebuah grup (data kategori) mempunyai varians yang sama diantara anggota grup tersebut.

\section{Uji Korelasi Antar Variabel Independen}

Pengujian ini bertujuan untuk mengetahui apakah ada multikoleniaritas data.

\section{Uji Outlier}


Pengujian ini dilakukan melalui deteksi data dengan standarisasi yang pada prinsipnya mengubah nilai data semula menjadi dalam bentuk $\mathrm{z}$, dan kemudian menafsir nilai z tersebut (Santoso, 2017:32-35).

\section{HASIL DAN PEMBAHASAN}

\section{Pembahasan}

Karakteristik responden dalam penelitian ini dapat dijelaskan dalam tabel di bawah ini:

Tabel 1

Jumlah Responden Berdasarkan Jenis Kelamin

\begin{tabular}{|c|c|c|c|}
\hline No & $\begin{array}{c}\text { Jenis } \\
\text { Kelamin }\end{array}$ & Jumlah & Persentase \\
\hline 1 & Laki-laki & 21 & $21 \%$ \\
\hline 2 & Perempuan & 79 & $79 \%$ \\
\hline \multicolumn{2}{|c|}{ Jumlah } & 100 & $100 \%$ \\
\hline
\end{tabular}

Sumber: Hasil Olah Data Kuesioner, 2020.

Berdasarkan tabel 1 di atas, dapat diketahui bahwa responden berjenis kelamin laki-laki yaitu berjumlah 21 orang $(21 \%)$, sedangkan responden berjenis kelamin perempuan yaitu berjumlah 79 orang (79\%). Hal ini menunjukan bahwa dalam penelitian ini, reponden didominasi oleh perempuan.

Tabel 2

Jumlah Responden Berdasarkan Usia

\begin{tabular}{|c|c|c|c|c|}
\hline No & Usia & Generasi & Jumlah & Persentase \\
\hline 1 & $\begin{array}{c}43-26 \\
\text { tahun }\end{array}$ & $\mathrm{Y}$ & 11 & $11 \%$ \\
\hline 2 & $\begin{array}{c}25-8 \\
\text { tahun }\end{array}$ & $\mathrm{Z}$ & 89 & $89 \%$ \\
\hline \multicolumn{3}{|c|}{ Jumlah } & 100 & $100 \%$ \\
\hline
\end{tabular}

Sumber: Hasil Olah Data Kuesioner, 2020.

Berdasarkan tabel 2 di atas, dapat diketahui bahwa responden dengan jarak usia 43-26 tahun (generasi Y) yaitu berjumlah 11 orang (11\%), sedangkan responden dengan jarak usia 25-8 tahun (generasi Z) yaitu berjumlah 89 orang 
(89\%). Hal ini menunjukan bahwa dalam penelitian ini, responden didominasi oleh generasi Z.

Tabel 3

Jumlah Responden Berdasarkan Pendapatan

\begin{tabular}{|c|c|c|c|}
\hline No & Pendapatan & Jumlah & Persentase \\
\hline 1 & $\begin{array}{c}<\mathrm{Rp} . \\
1500.000\end{array}$ & 51 & $51 \%$ \\
\hline 2 & $\begin{array}{c}\text { Rp. } 1500.000 \\
-3.000 .000\end{array}$ & 18 & $18 \%$ \\
\hline 3 & $\begin{array}{c}\text { Rp. } 3.000 .000 \\
-5.000 .000\end{array}$ & 17 & $17 \%$ \\
\hline 4 & $\begin{array}{c}>\text { Rp. } \\
5.000 .000\end{array}$ & 14 & $14 \%$ \\
\hline \multicolumn{2}{|c|}{ Jumlah } & 100 & $100 \%$ \\
\hline \multicolumn{2}{|c|}{ Sumb: Hail Ola Dan Kusion 2020} \\
\hline
\end{tabular}

Sumber: Hasil Olah Data Kuesioner, 2020.

Berdasarkan tabel 3 di atas, dapat diketahui bahwa responden dengan pendapatan < Rp. 1.500 .000 yaitu berjumlah 51 orang (51\%), selanjutnya responden dengan pendapatan Rp. 1.500 .000 - 3.000.000 yaitu berjumlah 18 orang (18\%), kemudian responden dengan pendapatan Rp. 3.000 .000 5.000.000 yaitu berjumlah 17 orang (17\%), sedangkan responden dengan pendapatan > Rp. 5.000.000 yaitu berjumlah 14 orang (14\%). Hal ini menunjukan bahwa dalam penelitian ini, didominasi oleh responden dengan pendapatan perbulan $<$ Rp. 1.500.000. 
Tabel 4

Jumlah Responden Berdasarkan Pengeluaran

\begin{tabular}{|c|c|c|c|}
\hline No & Pengeluaran & Jumlah & Persentase \\
\hline 1 & $\begin{array}{c}<\mathrm{Rp} . \\
1500.000\end{array}$ & 59 & $59 \%$ \\
\hline 2 & $\begin{array}{c}\text { Rp. } 1500.000- \\
3.000 .000\end{array}$ & 25 & $25 \%$ \\
\hline 3 & $\begin{array}{l}\text { Rp. } 3.000 .000 \\
-5.000 .000\end{array}$ & 16 & $16 \%$ \\
\hline 4 & $\begin{array}{c}>\mathrm{Rp} . \\
5.000 .000\end{array}$ & 0 & $0 \%$ \\
\hline & Jumlah & 100 & $100 \%$ \\
\hline
\end{tabular}

Sumber: Hasil Olah Data Kuesioner, 2020.

Berdasarkan tabel 4 di atas, dapat diketahui bahwa responden dengan pengeluaran < Rp. 1.500 .000 yaitu berjumlah 59 orang (59\%), selanjutnya responden dengan pengeluaran Rp. $1.500 .000-3.000 .000$ yaitu berjumlah 25 orang (25\%), kemudian responden dengan pengeluaran Rp. $3.000 .000-$ 5.000.000 yaitu berjumlah 16 orang (16\%), sedangkan responden dengan pengeluaran > Rp. 5.000.000 yaitu tidak ada (0\%). Hal ini menunjukan bahwa dalam penelitian ini, didominasi oleh responden dengan pengeluaran perbulan < Rp. 1.500.000.

Tabel 5

Jumlah Responden Berdasarkan Tingkat Pembelian

\begin{tabular}{|c|c|c|c|}
\hline No & $\begin{array}{c}\text { Tingkat } \\
\text { Pembelian }\end{array}$ & Jumlah & Persentase \\
\hline 1 & Sering & 50 & $50 \%$ \\
\hline 2 & $\begin{array}{c}\text { Tidak } \\
\text { Sering }\end{array}$ & 50 & $50 \%$ \\
\hline \multicolumn{2}{|c|}{ Jumlah } & 100 & $100 \%$ \\
\hline
\end{tabular}

Sumber: Hasil Olah Data Kuesioner, 2020. 
Berdasarkan tabel 5 di atas, dapat diketahui bahwa jumlah responden yang sering dengan yang tidak sering melakukan pembelian impulsif sama, yaitu berjumlah 50 responden pada masing-masing tingkatan. Hal ini dikarenakan sebelum melakukan pengujian menggunakan analisis diskriminan, maka perlu membagi data ke dalam dua kelompok.

\section{UJI ASUMSI DISKRIMINAN}

\section{Uji Normalitas}

Uji normalitas pada multivarat bisa dilakukan pada setiap variabel dengan logika bahwa jika secara individual masing-masing variabel memenuhi asumsi normalitas, maka secara bersama-sama (multivariat) variabel-variabel tersebut juga dianggap telah memenuhi asumsi normalitas.

Dari hasil uji normalitas multivariat diperoleh nilai koefisien korelasi yaitu 0,952 yang menunjukan koefisien korelasi yang sangat tinggi. Besarnya koefisien korelasi berada di antara -1 sampai dengan +1 , kemudian besar nilai Sig. yang rinciannya dapat dilihat pada tabel 6 yaitu $0,000<0,05$.

\section{Tabel 6}

Tabel Correlations

\begin{tabular}{|cc|c|c|}
\hline & $\begin{array}{c}\text { Mahalanobis } \\
\text { Distance }\end{array}$ & Qi \\
\hline $\begin{array}{c}\text { Mahalanobis } \\
\text { Distance }\end{array}$ & $\begin{array}{c}\text { Pearson } \\
\text { Correlation } \\
\text { Sig. }(2- \\
\text { tailed) } \\
\mathrm{N}\end{array}$ & 1 & 0,95 \\
$2^{* *}$ \\
Qi & $\begin{array}{c}\text { Pearson } \\
\text { Correlation } \\
\text { Sig. (2- } \\
\text { tailed) } \\
\mathrm{N}\end{array}$ & $0,952^{* *}$ & 1 \\
\hline \multirow{2*}{*}{ Correlation is significant at the 0.01 level (2- } \\
tailed).
\end{tabular}

Sumber: Hasil Olah IBM SPSS V.23, 2020.

\section{Uji Kesamaan Matriks Varians-Kovarians}

Uji ini pada prinsipnya bertujuan untuk mengetahui apakah sebuah grup (data kategori) mempunyai varians yang sama diantara anggota grup tersebut. Jika varian sama, dan ini yang seharusnya terjadi, maka dikatakan ada 
Homoskedastisitas. Sedangkan jika varian tidak sama, dikatakan terjadi Heteroskedastisitas.

Dari hasil uji kesamaan matriks varians-kovarians diperoleh nilai Sig. masing-masing variabel kecuali variabel jenis_kelamin dengan dasar mean, didapat angka Sig. output SPSS pada tabel 7 yaitu >0,05. Dengan demikian dapat diartikan bahwa grup kovarians matrik relatif sama (Homokedastisitas). Pada variabel jenis_kelamin diperoleh angka Sig. pada mean yaitu 0,001 (tolak $H_{0}$ ), akan tetapi angka Sig. pada tabel median menunjukan penerimaan $H_{0}$. Dengan demikian untuk kasus ini terdapat pengecualian, dikarenakan data awal yaitu berbentuk variabel dummy (kategori laki-laki dan perempuan).

Tabel 7

Tabel Test of Homogenity of Variance

\begin{tabular}{|ll|c|}
\hline Variabel & & Sig. \\
\hline \multirow{2}{*}{ Usia } & based on mean & 0,985 \\
& based on median & 0,853 \\
\hline \multirow{2}{*}{ jenis_kelamin } & based on mean & 0,001 \\
& based on median & 0,087 \\
\hline Pendapatan & based on mean & 0,376 \\
& based on median & 0,662 \\
\hline Pengeluaran & based on mean & 0,429 \\
& based on median & 0,378 \\
\hline \multirow{2}{*}{ kualitas_web } & based on mean & 0,764 \\
& based on median & 0,964 \\
\hline \multirow{2}{*}{ kualitas_produk } & based on mean & 0,705 \\
& based on median & 0,674 \\
\hline \multirow{2}{*}{ Diskon } & based on mean & 0,795 \\
& based on median & 0,801 \\
\hline \multirow{2}{*}{ Mood } & based on mean & 0,514 \\
& based on median & 0,443 \\
\hline \multirow{2}{*}{ Situasional } & based on mean & 0,359 \\
& based on median & 0,458 \\
\hline \multirow{2}{*}{ display_toko } & based on mean & 0,221 \\
& based on median & 0,223 \\
\hline \multirow{2}{*}{ Swit }
\end{tabular}

Sumber: Hasil Olah IBM SPSS V.23, 2020. 


\section{Uji Korelasi Antar Variabel Independen}

Uji korelasi antar independen yang digunakan dalam penelitian ini yaitu dengan melihat nilai tolerance dan VIF pada tabel coefficient. Asumsi yang harus terpenuhi adalah tidak ada korelasi antara dua variabel independen. Jika dua variabel independen mempunyai korelasi yang kuat, maka dikatakan terjadi multikolinieritas.

Dari hasil uji korelasi antar variabel independen diperoleh nilai tolerance $>0,10$ dan nilai $V I F<10,0$. Dengan demikian dapat diartikan bahwa tidak terjadi gejala multikoleniaritas dalam penelitian ini.

Tabel 8

Tabel Coefficients

\begin{tabular}{|c|c|c|}
\hline \multirow[b]{2}{*}{ Model } & \multicolumn{2}{|c|}{ Collinearity Statistics } \\
\hline & Tolerance & VIF \\
\hline \multicolumn{3}{|l|}{$\begin{array}{ll}1 & \text { (Constant) }\end{array}$} \\
\hline Usia & 0,531 & 1,885 \\
\hline jenis_kelamin & 0,866 & 1,154 \\
\hline Pendapatan & 0,112 & 8,951 \\
\hline Pengeluaran & 0,122 & 8,177 \\
\hline kualitas_web & 0,751 & 1,332 \\
\hline kualitas_produk & 0,655 & 1,526 \\
\hline diskon & 0,768 & 1,302 \\
\hline mood & 0,785 & 1,273 \\
\hline situasional & 0,779 & 1,283 \\
\hline display_toko & 0,705 & 1,418 \\
\hline dent Vari & oulsif & \\
\hline
\end{tabular}

Sumber: Hasil Olah IBM SPSS V.23, 2020.

\section{Uji Outlier}

Uji outlier dalam penelitian ini dilakukan dengan membuat nilai $\mathrm{z}$ (standarisasi data), yang kemudian menafsirkan nilai $\mathrm{z}$ tersebut. Jika data dikategorikan sebagai data outlier, maka nilai z yang didapat terletak lebih besar dari angka $+2,5$ atau lebih kecil dari angka -2,5.

Berdasarkan hasil output SPSS, ditemukan bahwa semua variabel tidak ada data yang berada dibawah $-2,5$ ataupun diatas $+2,5$. Sehingga dapat disimpulkan bahwa tidak ada data yang outlier atau data yang ekstrem. 


\section{Analisis Diskriminan}

Metode analisis diskriminan yang digunakan dalam penelitian ini adalah Step-wise Estimation. Step-wise Estimation adalah metode dimana variabel dimasukkan satu per satu ke dalam model diskriminan. Pada proses ini tentu ada variabel yang tetap ada pada model dan ada kemungkinan satu atau lebih variabel independen yang dikeluarkan dalam model (Santoso, 2017:155). Setelah dilakukan pengujian tersebut, maka diperoleh variabel yang layak digunakan untuk analisis diskriminan adalah variabel pengeluara dan jenis kelamin (gender).

Setelah melewati berbagai pengujian dan telah diperoleh beberapa data yang layak untuk dianalisis, maka data tersebut sudah bisa untuk masuk kedalam proses analisis diskriminan. Dengan demikian diperoleh hasil dari analisis yang akan dijelaskan pada poin-poin dibawah ini.

\section{Perbedaan Kategori Konsumen}

Menurut (Santoso, 2017:181), proses penentu apakah terdapat perbedaan yang signifikan antar setiap kategori dapat dilihat dalam output SPSS pada tabel Wilk's Lambda.

Dari tabel tersebut, diperoleh angka Sig. yaitu 0,002, jika dibandingkan dengan kriteria uji yaitu $H_{0}$ ditolak pada saat angka Sig. $<0,05$, maka diperoleh hasil 0,002 $<0,05$. Dengan demikian $H_{0}$ ditolak dan $H_{I}$ diterima atau dengan kata lain terdapat perbedaan yang signifikan antar dua kategori konsumen Tokopedia dalam melakukan pembelian impulsif.

Tabel 9

Tabel Wilk's Lambda

\begin{tabular}{|c|c|}
\hline $\begin{array}{c}\text { Test of } \\
\text { Function(s) }\end{array}$ & Sig. \\
\hline 1 & 0,002 \\
\hline
\end{tabular}

Sumber: Hasil Olah IBM SPSS V.23, 2020.

\section{Faktor Yang Mempengaruhi Perbedaan Kategori Konsumen}

Langkah selanjutnya ialah mencari faktor apa saja yang mempengaruhi perbedaan dua kategori tersebut. Menurut Santoso (2017:169), untuk mengetahui faktor-faktor apa saja yang mempengaruhi perbedaan kategori tersebut, dapat dilihat dalam output SPSS pada tabel Variabel in the Analysis. 
Dari tabel tersebut, diperoleh dua variabel yang menjadi faktor pengaruh dari perbedaan kategori pembelian impulsif konsumen Tokopedia. Faktor yang pertama yaitu pendapatan, Sedangkan faktor yang kedua yaitu jenis kelamin.

Kemudian, jika dilihat dari angka Sig. of $F$ to Remove kedua faktor tersebut memiliki hasil yaitu $<0,05$, hal ini berarti dua variabel independen tersebut dapat digunakan untuk mengidentifikasi perbedaan antar kategori. Jadi kedua variabel independen tersebut layak dan dapat digunakan untuk analisis diskriminan.

Tabel 10

Tabel Variabel in the Analysis

\begin{tabular}{|ll|c|}
\hline \multicolumn{1}{|c|}{ Step } & Sig. of F to Remove \\
\hline 1 & Pendapatan & 0,015 \\
\hline 2 & Pendapatan & 0,002 \\
& jenis_kelamin & 0,012 \\
\hline
\end{tabular}

Sumber: Hasil Olah IBM SPSS V.23, 2020.

\section{Model Diskriminan Dua Faktor Yang Terbentuk}

Menurut Santoso (2017:173), untuk menentukan persamaan model diskriminan yang akan terbentuk, maka dapat dilihat dalam output SPSS pada tabel Canonical Discriminant Function Coefficients.

Jika dilihat didalam tabel tersebut, maka diperoleh fungsi diskriminan dengan persamaan (4.1) yaitu, Zscore $=-13,737$ (konstan) $+1,911$ (jenis_kelamin) $+0,875$ (pendapatan). Dengan demikian fungsi ini berguna untuk menganalisa kasus atau responden yang diteliti akan masuk ke dalam kelompok apa, apakah kelompok pertama (keputusan 0) atau kelompok kedua (keputusan 1).

\section{Tabel 11}

Tabel Canonical Discriminant Function Coefficients.

\begin{tabular}{|c|c|}
\hline & Function \\
\cline { 2 - 2 } & 1 \\
\hline jenis_kelamin & 1,911 \\
pendapatan & 0,875 \\
(Constant) & $-13,737$ \\
\hline Unstandardized coefficients \\
\hline
\end{tabular}

Sumber: Hasil Olah IBM SPSS V.23, 2020. 


\section{Ketepatan Hasil Klasifikasi Model Diskriminan}

Menurut Santoso (2017:180), untuk menentukan ketepatan validasi ini, dapat dilihat dalam output SPSS pada tabel Classification Results ${ }^{\mathrm{a}, \mathrm{c}}$.

Setelah dianalisis, terdapat 41 responden yang meleset dari kategori pada data awal. Responden yang pada data awal berada pada kategori sering dan setelah diklasifikasi fungsi diskriminan tetap pada kategori sering sebanyak 26 orang. Sedangkan responden yang awalnya berada pada katgori tidak sering dan tetap pada kategori tersebut, yaitu sebanyak 33 orang.

Tabel 11

Tabel Classification Results ${ }^{a, c}$.

\begin{tabular}{|c|c|c|c|c|}
\hline \multirow{2}{*}{\multicolumn{2}{|c|}{ Impulsif }} & \multicolumn{2}{|c|}{$\begin{array}{c}\text { Predicted Group } \\
\text { Membership }\end{array}$} & \multirow{2}{*}{ Total } \\
\hline & & sering & $\begin{array}{l}\text { tidak } \\
\text { sering }\end{array}$ & \\
\hline Original & $\begin{array}{c}\text { Sering } \\
\text { tidak } \\
\text { sering }\end{array}$ & $\begin{array}{l}26 \\
17\end{array}$ & $\begin{array}{l}24 \\
33\end{array}$ & $\begin{array}{l}50 \\
50\end{array}$ \\
\hline
\end{tabular}

Lanjutan

Tabel Classification Results ${ }^{a, c}$.

\begin{tabular}{|c|c|c|c|c|}
\hline & $\begin{array}{l}\text { sering } \\
\text { tidak } \\
\text { sering }\end{array}$ & $\begin{array}{l}52 \\
34\end{array}$ & $\begin{array}{l}48 \\
66\end{array}$ & $\begin{array}{l}100 \\
100\end{array}$ \\
\hline \multirow{2}{*}{$\begin{array}{l}\text { Cross- } \\
\text { validated }^{\mathrm{b}}\end{array}$} & $\begin{array}{l}\text { sering } \\
\text { tidak } \\
\text { sering }\end{array}$ & $\begin{array}{l}26 \\
17\end{array}$ & $\begin{array}{l}24 \\
33\end{array}$ & $\begin{array}{l}50 \\
50\end{array}$ \\
\hline & $\begin{array}{l}\text { sering } \\
\text { tidak } \\
\text { sering }\end{array}$ & $\begin{array}{l}52 \\
34\end{array}$ & $\begin{array}{l}48 \\
66\end{array}$ & $\begin{array}{l}100 \\
100\end{array}$ \\
\hline
\end{tabular}

a. $59,0 \%$ of original grouped cases correctly classified.

b. Cross validation is done only for those cases in the analysis. In cross validation, each case is classified by the functions derived from all cases other than that case.

c. $59,0 \%$ of cross-validated grouped cases correctly classified.

Sumber: Hasil Olah IBM SPSS V.23, 2020.

Berdasarkan tabel diatas, maka diperoleh hasil ketepatan prediksi dari model ialah sebesar 59\%, dengan demikian model diskriminan layak digunakan 
untuk analisis diskriminan atau valid digunakan pada penelitian ini karena diperoleh ketepatan $>50 \%$.

\section{PENUTUP}

\section{Kesimpulan}

Berdasarkan hasil analisis data dan pembahasan, maka kesimpulan yang dapat peneliti kemukakan adalah :

1. Terdapat perbedaan yang signifikan sebesar 0,002 antara konsumen yang sering dengan konsumen yang tidak sering melakukan pembelian secara impulsif di Tokopedia.

2. Faktor - faktor yang mempengaruhi perbedaan tingkat pembelian impulsif konsumen Tokopedia adalah perbedaan jenis kelamin konsumen dan tingkat pendapatan konsumen selama sebulan.

3. Model diskriminan dua faktor yang terbentuk adalah Zscore $=-13,737+$ 1,911 (jenis kelamin) $+0,875$ (pendapatan)

4. Pengujian validasi pada penelitian diperoleh angka ketepatan hasil yaitu $59 \%$.

\section{Saran}

Berdasarkan pengalaman selama mengadakan penelitian maka saransaran yang dapat dikemukakan adalah sebagai berikut :

1. Untuk melakukan analisis diskriminan sebaiknya melakukan pengambilan data konsumen melebihi batas yang ditentukan.

2. Memastikan semua pengujian asumsi dapat terpenuhi, agar diperoleh model diskriminan dengan tingkat ketepatan yang lebih tinggi.

3. Pihak marketplace dapat melakukan inovasi dalam mempromosikan produk-produk, yang disesuaikan dengan kebutuhan dari masing-masing kategori jenis kelamin (laki-laki/ perempuan).

4. Selain itu Tokopedia juga dapat melakukan sebuah penawaran harga yang disesuaikan dengan tingkat pendapatan dari berbagai kalangan konsumen. 


\section{DAFTAR PUSTAKA}

Godara, Sagarika \& Bishnoi, Vinod Kumar. 2019. A study on influence of website quality on online impulse buying behavior of Indian consumer. Journal of The Gujarat Research Society. 21(10). ISSN: 0374-8588.

Kotler, Philip dan Keller, Kevin Lan. 2016. Manajemen Pemasaran. Jakarta: Erlangga.

Levy, Michael dan Weitz, Barton A. 2012. Retailing Management. New York: McGraw-Hill.

Mowen, J.C dan Minor. 2010. (hlm. 106). Consumer Behavior. Amerika Serikat: Prestice Hall. Inc.

Renanita, Theda. 2017. Kecenderungan Pembelian Impulsif Online Ditinjau dari Penjelajahan Website Yang Bersifat Hedonis dan Jenis Kelamin pada Generasi Y. Indigenous: Jurnal Ilmiah Psikologi. 2(1). ISSN: 2541-450X.

Santoso, Singgih. 2017. Statistik Multivariat Dengan SPSS. Jakarta: Elex Media Kumputindo

Sari, Nilam Anggar \& Indrawati, Farida. 2018. Pengaruh Shopping Lifestyle Dan Fashion Involvement Terhadap Impulse Buying Behavior Pada "Butik Kanabini” Di Tenggarong. JEMI. 18(2). ISSN: 536-1408.

Simamora, Henry. 2010. Manajemen Pemasaran. Jilid II. Cetakan Pertama. Jakarta: Salemba Empat.

Sugiyono. 2019. Metode Penelitian \& Pengembangan (Research and Development). Bandung: Alfabeta.

Utami, Christina Whidya. 2018. Manajemen Ritel (Strategi dan Implementasi Operasional Bisni Ritel Modern di Indonesia). Jakarta: Salemba. 